\title{
MEMPERKENALKAN PERMAINAN JUMANTIK SEBAGAI MEDIA EDUKASI UNTUK MELATIH MASYARAKAT MEMANTAU JENTIK NYAMUK
}

\author{
Dian Puspita Sari*), Titi Pambudi Karuniawati, Dewi Suryani, Yoga P. Susani, \\ Program Studi Pendidikan Dokter Fakultas Kedokteran Universitas Mataram \\ Jalan Pendidikan No 37 Mataram Nusa Tenggara Barat \\ *Alamat korespondensi: dianps@unram.ac.id
}

\begin{abstract}
ABSTRAK
Demam Berdarah Dengue (DBD) adalah salah satu tantangan kesehatan di Indonesia, khususnya di Kota Mataram. Perilaku manusia dapat mempengaruhi ekologi vektor dan siklus transmisi penyakit, karena itu upaya pengendalian vektor DBD harus melibatkan peran serta masyarakat dalam mengelola lingkungannya. Pelibatan masyarakat sejak usia belia dapat membentuk perilaku pencegahan yang diharapkan serta mendorong perubahan perilaku pada orang dewasa. Board game merupakan salah satu alternatif metode pembelajaran yang dapat digunakan pada anak maupun dewasa. Selain menyenangkan, penyampaian pesan edukatif melalui permainan dapat meningkatkan luaran kognitif dan perilaku yang diharapkan dari permainan tersebut. Media board game pemantauan jentik dapat pula digunakan untuk mendukung program pemberantasan sarang nyamuk (PSN) pada anak sekolah. Kegiatan ini bertujuan untuk memberikan edukasi kepada masyarakat terkait pemberantasan sarang nyamuk melalui media permainan yang diberi judul JUMANTIK. Pada kegiatan pengabdian kepada masyarakat ini, sebanyak 20 orang memainkan permainan JUMANTIK dan sembilan di antaranya adalah anak-anak. Hasil dari pelaksanaan kegiatan pengabdian kepada masyarakat ini adalah peningkatan pengetahuan terkait Demam Berdarah Dengue setelah memainkan permainan Jumantik, terutama pada aspek pencegahan breeding site nyamuk. Pada anak-anak, permainan ini meningkatkan kesediaan mereka untuk ikut memantau jentik nyamuk di rumah dan di sekolah. Sementara pada peserta dewasa permainan ini mampu meningkatkan kesetujuan akan peran anak-anak dalam pemberantasan sarang nyamuk di sekolah. Permainan ini dinilai menarik dan bermanfaat oleh anak-anak maupun dewasa. Kesimpulan yang dapat diambil adalah permainan Jumantik dapat menjadi salah satu media edukasi untuk meningkatkan pengetahuan dan sikap anak-anak maupun dewasa terkait pencegahan DBD di rumah dan sekolah.
\end{abstract}

Kata Kunci: Demam Berdarah Dengue, pemantauan jentik, pemberantasan sarang nyamuk 


\section{PENDAHULUAN}

Demam Berdarah Dengue (DBD) merupakan tantangan kesehatan global. Setiap tahun diperkirakan terjadi 50 juta infeksi dan secara global terdapat 2.5 miliar penduduk berisiko yang mendiami daerah endemis. Negara-negara di kawasan Asia Tenggara termasuk Indonesia merupakan kawasan endemis karena beriklim tropis (WHO, 2009). Meskipun angka kematian akibat DBD di Indonesia mengalami penurunan, namun insidensi DBD di Indonesia menunjukkan tren yang meningkat (Karyanti et al., 2014). Indonesia juga merupakan negara endemis tertinggi kedua setelah Brazil (WHO, 2012).

Di Kota Mataram, insidensi DBD menurun dari 15.03 pada tahun 2008 menjadi 14.86 pada tahun 2016, namun angka kematian menunjukkan peningkatan dari 0.3 menjadi 1.04 . Data dari Dinas Kesehatan Kota Mataram juga menemukan bahwa kelompok usia 5-14 tahun merupakan kelompok penderita DBD terbesar sepanjang semester pertama tahun
2016 (Dinas Kesehatan Kota Mataram, 2016).

Virus Dengue terutama disebarkan oleh nyamuk Aedes aegypti yang juga berkontribusi menyebarkan penyakit lain seperti Zika dan Chikungunya. Penyebaran virus Dengue melibatkan interaksi yang kompleks antar berbagai aktor (virus, vektor dan manusia) dalam lingkungan, dan dipengaruhi oleh berbagai faktor seperti iklim mikro, tingkat perkembangan daerah perkotaan, tata ruang kota dan kepadatan populasi (Mohammed \& Chadee, 2011). Meskipun saat ini vaksin untuk pencegahan Dengue sudah tersedia (Dengvaxia) namun efektivitas proteksi yang ditawarkan terbatas terutama pada anak-anak berusia di bawah sembilan tahun (Aguiar et al., 2016). Hal ini mendorong pentingnya pencegahan penyakit ini melalui pengendalian dan surveilan vektor nyamuk.

Perilaku manusia, baik secara perorangan maupun berkelompok dapat mempengaruhi ekologi vektor dan siklus transmisi penyakit (Padmanabha et al., 2010), contohnya 
perilaku cara menampung air. Perilaku ini dapat meningkatkan tempat perkembangbiakan vektor yang pada gilirannya meningkatkan jumlah kasus DBD di populasi. Oleh karena itu, upaya pengendalian vektor DBD harus melibatkan peran serta masyarakat.

Salah satu metode pencegahan Dengue adalah manajemen lingkungan. Manajemen lingkungan merupakan upaya untuk memodifikasi dan atau memanipulasi faktor lingkungan atau interaksinya dengan manusia untuk mencegah atau mengurangi perkembangbiakan vektor dan kontak antara manusia-vektorvirus. Manajemen lingkungan ini dibagi menjadi 3 yaitu: modifikasi lingkungan, misalnya pemeriksaan jentik nyamuk pada tempat penampungan air, manipulasi lingkungan misalnya menguras dan menutup tempat penampungan air atau membersihkan genangan air yang tidak terduga dan perilaku memproteksi diri dari gigitan nyamuk seperti menggunakan repellent atau kelambu (WHO, 2011).

Kesadaran akan pentingnya pelibatan anak-anak usia sekolah dalam pencegahan Dengue telah ditemukan dalam literatur. Anak-anak penting memahami konsep pencegahan Dengue sejak awal agar dapat membentuk perilaku pencegahan yang diharapkan. Anakanak juga dapat mendorong perubahan perilaku pada orang tua (Winch et al., 2002). Kegiatan pencegahan DBD yang melibatkan anak-anak juga ditemukan di Indonesia antara lain dalam bentuk kegiatan PSN pada anak sekolah. Kegiatan ini meliputi pengamatan jentik dan kegiatan $3 \mathrm{M}$ yang terdiri dari menutup, menguras, dan memanfaatkan barang-barang bekas yang masih bernilai ekonomis. Pelaksanaan PSN ini melibatkan siswa dan seluruh warga sekolah termasuk guru. Guru berperan untuk membuat laporan hasil program PSN, memeriksa,

mengajarkan/mengarahkan dan mengawasi pelaksanaan program PSN ini (Kemenkes RI, 2014).

Pada kenyataannya, belum semua sekolah di Kota Mataram rutin melaksanakan pemantauan jentik dan pemberantasan sarang nyamuk (Josafat et al., 2016). Jumlah sekolah 
yang sudah pernah mendapatkan pelatihan Jumantik (Juru Pemantau Jentik) juga terbatas. Siswa yang telah dilatih tidak lantas dapat mengimplementasikan hasil pelatihan di sekolah dan hasil studi menunjukkan rendahnya keberlanjutan program ini karena keterbatasan pengetahuan, keterampilan dan media pembelajaran yang tersedia bagi sekolah untuk melatih siswa SD melakukan pemantauan jentik untuk pencegahan DBD.

Salah satu metode nonkonvensional yang telah digunakan untuk memberikan edukasi mengenai pencegahan DBD adalah melalui permainan. Board game atau permainan papan dapat meningkatkan pengetahuan terkait kesehatan, mendorong motivasi belajar dan 2018). Permainan papan juga melibatkan interaksi dengan pemain lain sehingga mampu melatih keterampilan sosial partisipan (Mostowfi, 2016). Metode ini menjadi salah satu alternatif metode pembelajaran di samping metode konvensional seperti ceramah dan perilaku positif pada (Viggiano et al.,

diskusi (Giannakos, 2013). Keunggulan utama permainan papan adalah menyenangkan dan mengandung unsur permainan (Ober, 2016). Permainan yang menyenangkan dapat meningkatkan luaran kognitif dan perilaku yang diharapkan dari permainan tersebut (Giannakos, 2013).

Kegiatan pengabdian kepada masyarakat ini bertujuan untuk memberikan edukasi kepada masyarakat, baik anak dan dewasa mengenai pemantauan jentik nyamuk untuk pencegahan DBD melalui media permainan. Manfaat yang diharapkan dari kegiatan ini adalah meningkatnya pengetahuan dan sikap serta peran serta masyarakat dalam kegiatan pencegahan Demam Berdarah Dengue di Kota Mataram.

\section{METODE KEGIATAN}

Kegiatan ini dilaksanakan pada bulan September hingga Oktober 2018, namun persiapan pengembangan permainan telah dilaksanakan sejak bulan Mei 2018 oleh tim penelitian Demam Berdarah Dengue (DBD) Fakultas Kedokteran Universitas Mataram (FK UNRAM) 102

Available online : http://abdiinsani.unram.ac.id 
bersama DAKON, pengembang board game dari Yogyakarta.

Deskripsi

proses

pengembangan permainan JUMANTIK

dipublikasikan secara terpisah (dalam proses), namun secara garis besar, tim peneliti DBD FK UNRAM menetapkan tujuan permainan, nilai (value) yang diutamakan dalam permainan serta konten pengetahuan yang akan dimasukkan. Desain mekanik dan visual dikerjakan oleh DAKON. Permainan yang dirancang adalah permainan kartu. Dalam permainan JUMANTIK, para pemain diberikan misi untuk memasangkan potential breeding site Aedes aegypti dengan cara pencegahan yang tepat (menguras, menutup, mendaur ulang, serta mencegah gigitan nyamuk). Permainan ini dirancang untuk dimainkan oleh 3-4 pemain mulai dari anak-anak usia SD kelas 3 hingga dewasa. Dalam permainan ini, setiap pemain harus mengumpulkan kartu aksi yang tepat untuk mengerjakan misi yang didapatkan. Setiap berhasil menyelesaikan satu misi, pemain akan mendapat skor sesuai dengan yang tertera di kartu misi. Pemenang dalam permainan ini adalah pemain yang mengumpulkan skor terbanyak.

Setelah purwarupa awal permainan selesai, tim pelaksana kegiatan pengabdian kepada masyarakat menguji coba permainan dalam tim serta berlatih menjadi pendamping permainan. Selain itu, tim juga merancang kuesioner pengetahuan dan sikap serta umpan balik terhadap permainan. Kuesioner dirancang dengan bahasa yang sederhana agar dapat dipahami oleh pemain anak-anak karena permainan ini dirancang untuk dapat dimainkan oleh anak usia SD (kelas 3).

Kuesioner pengetahuan terdiri dari 35 pertanyaan yang mengujikan 3 aspek: (A) penyakit Dengue (penularan, gejala, vektor dan lingkungan tempat berkembang biak vektor), (B) breeding site nyamuk Aedes aegypti dan cara pencegahan perkembangbiakan nyamuk serta (C) cara pencegahan gigitan nyamuk.

Kuesioner sikap untuk pemain anak-anak dibedakan dari pemain dewasa. Kuesioner sikap pada anak terdiri atas 22 pernyataan yang direspon dengan tiga pilihan jawaban: 
setuju, ragu-ragu dan tidak setuju. Kuesioner sikap mengukur beberapa aspek: (1) sikap terhadap penyakit Dengue (item no 1 sd 3), (2) sikap terhadap peran serta masyarakat dalam pencegahan penyakit Dengue (item no 4 sd 7), (4) persepsi kemampuan diri (self-efficacy) dalam tindakan pencegahan penyakit (item no 9 sd 14), (5) kesediaan untuk melakukan tindakan pencegahan di rumah dan di sekolah (item no 15 sd 20) dan (6) sikap terhadap fogging ( item no 8, 21, 22).

$$
\text { Untuk pemain dewasa, }
$$
kuesioner sikap terdiri atas 25 pertanyaan dengan lima pilihan jawaban tipe Likert yaitu Sangat Setuju, Setuju, Ragu-ragu, Tidak Setuju dan Sangat Tidak Setuju. Kuesioner sikap pada pemain dewasa menilai beberapa aspek yang sama dengan kuesioner pada anak yaitu: (1) sikap terhadap penyakit Dengue (item no 1 sd 3), (2) sikap terhadap peran serta masyarakat dalam pencegahan penyakit Dengue (item no 4 sd 7), (4) persepsi kemampuan diri (selfefficacy) dalam tindakan pencegahan penyakit ( item no 9 sd 14), (5) kesediaan untuk melakukan tindakan pencegahan di rumah (item no $15 \mathrm{sd}$ 20), (6) sikap mengenai peran serta anak-anak dalam tindakan pencegahan penyakit Dengue (15 sd 22) dan (7) sikap terhadap fogging ( item no 8, 23, 24, 25).

Untuk menilai umpan balik pemain terhadap permainan JUMANTIK, digunakan kuesioner dengan skala smileyometer (gambar 1). Terdapat 12 item pertanyaan terkait umpan balik. Pemain memberikan respon dengan memilih salah satu dari lima pilihan smileyometer yang diberikan skor 0 (sangat tidak tertarik untuk bermain / sangat sulit / sangat tidak bagus / sangat tidak sesuai) hingga 4 (sangat ingin segera bermain / sangat mudah / sangat bagus / sangat sesuai). 


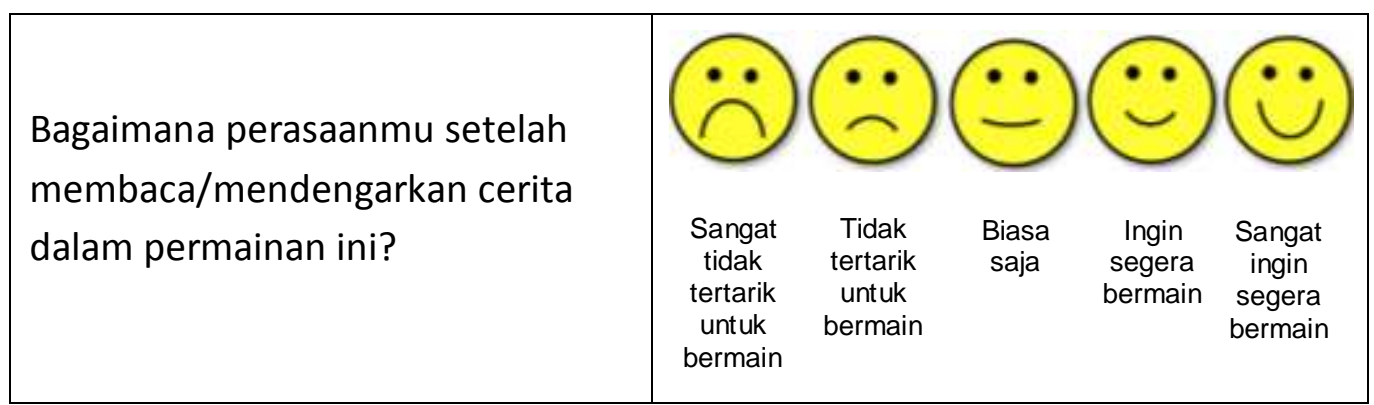

Gambar 1. Skala smileyometer

Setelah kuesioner dan set permainan siap, permainan ini kemudian diperkenalkan kepada masyarakat melalui kegiatan bermain informal di lingkungan perumahan di Kota Mataram dan di lingkungan perkantoran, antara lain pada pada petugas kesehatan di RS Universitas

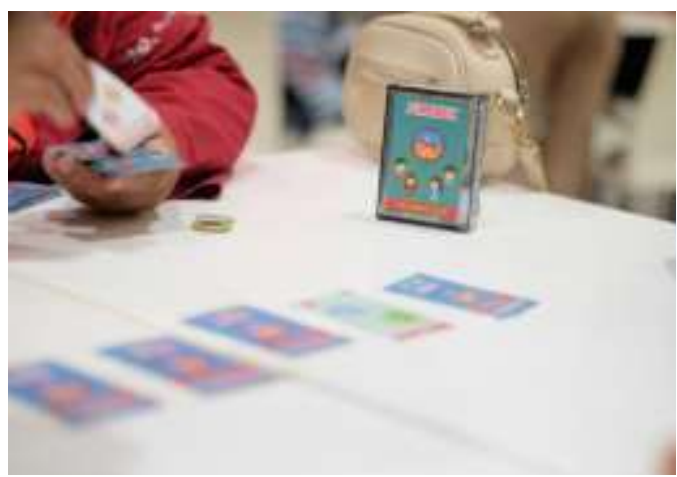

Gambar 2. Set Permainan JUMANTIK

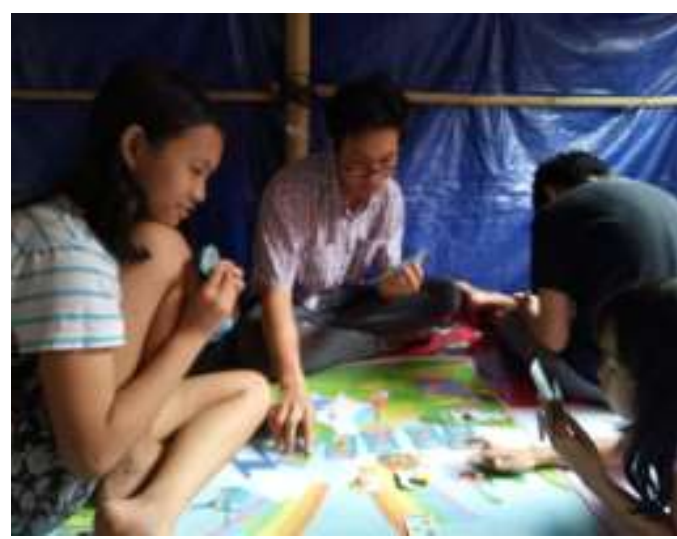

Gambar 4. Sesi bermain JUMANTIK dengan anak-anak
Mataram. Sebelum memulai permainan, setiap peserta diminta untuk mengisi kuesioner pengetahuan dan sikap sebagai pretes. Setelah bermain, peserta mengisi postes yang sama seperti sebelum bermain serta mengisi kuesioner umpan balik.

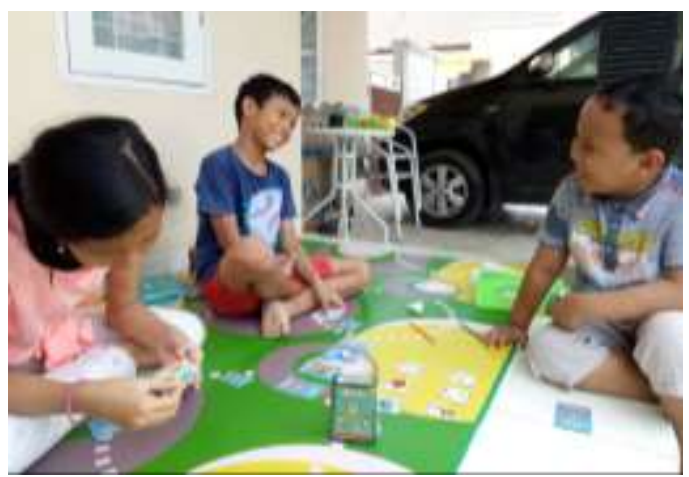

Gambar 3. Sesi bermain JUMANTIK dengan anak-anak

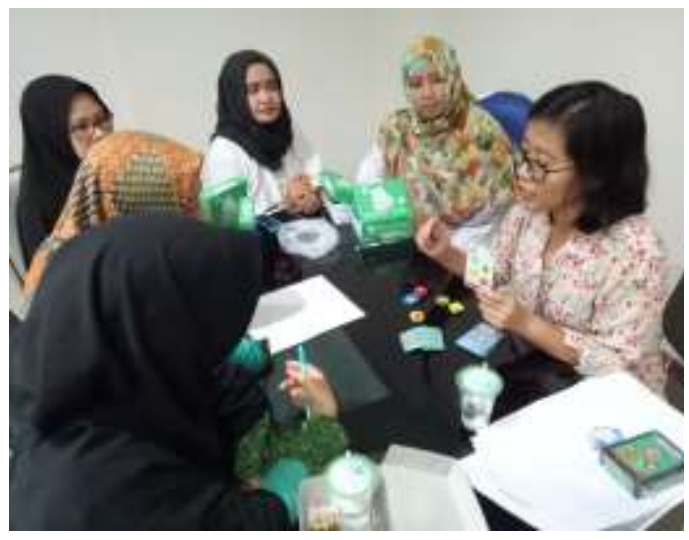

Gambar 5. Sesi bermain JUMANTIK dengan dewasa 


\section{HASIL DAN PEMBAHASAN}

Dalam kegiatan pengabdian kepada masyarakat ini, permainan Jumantik dimainkan oleh 20 orang: 9 orang di antaranya adalah anak-anak usia SD hingga SMA dan sisanya dewasa. Peserta termuda yang ikut memainkan game ini berusia 8 tahun dan tertua 35 tahun.

Pengetahuan
Secara umum, terdapat peningkatan pengetahuan pada seluruh peserta (anak dan dewasa) setelah memainkan Jumantik (Tabel 1. Skor pengetahuan sebelum dan sesudah bermain Jumantik). Peningkatan pengetahuan terbesar terjadi pada bagian B, yaitu bagian yang mengujikan mengenai jenis breeding site nyamuk dan cara pencegahannya. Hal ini sesuai dengan tujuan permainan Jumantik.

Table 1. Skor pengetahuan sebelum dan sesudah bermain Jumantik

\begin{tabular}{lll}
\hline & $\begin{array}{l}\text { Pretes } \\
\text { Mean } \pm \text { SD }\end{array}$ & $\begin{array}{l}\text { Postes } \\
\text { Mean } \pm \text { SD }\end{array}$ \\
\hline $\begin{array}{ll}\text { Pengetahuan dewasa }(\mathrm{N}=11) \\
\text { Bagian A }\end{array}$ & $90 \pm 10$ & $90.9 \pm 9.4$ \\
$\quad$ Bagian B & $84.9 \pm 15.5$ & $92.7 \pm 10.9$ \\
Bagian C & $93.6 \pm 9.2$ & $93.6 \pm 8.1$ \\
Total & $88.8 \pm 9.0$ & $92.5 \pm 5.8$ \\
& & \\
Pengetahuan anak (N = 9) & & \\
Bagian A & $76.7 \pm 8.6$ & $82.2 \pm 8.3$ \\
Bagian B & $59.3 \pm 27.4$ & $80 \pm 11.6$ \\
Bagian C & $91.1 \pm 11.7$ & $91.1 \pm 13.6$ \\
Total & $73.3 \pm 12.0$ & $83.9 \pm 7.8$ \\
\hline
\end{tabular}

Sikap

mengenali jentik nyamuk. Kesediaan

Sebelum bermain game melakukan tindakan pencegahan di Jumantik, mayoritas pemain anak- rumah dan di sekolah juga rendah. anak sudah memiliki sikap yang baik terkait penyakit Dengue dan peran serta masyarakat dalam pencegahan penyakit ini, namun kurang memiliki Setelah bermain game, kesediaan anak-anak dalam mengenali jentik nyamuk di rumah (item no 17) dan di sekolah (item no 20) meningkat sama self-efficacy untuk terlibat dalam atau lebih dari 30\%, namun aspek tindakan pencegahan penyakit seperti sikap lainnya tidak mengalami 
perubahan atau berubah kurang dari $30 \%$.

Pemain dewasa rata-rata memiliki sikap yang baik terkait Demam Berdarah Dengue dan persepsi mengenai partisipasi masyarakat dalam pencegahan DBD. Tidak ada perbedaan sikap sebelum dan sesudah permainan terkait dua aspek tersebut. Terkait dengan peran anak-anak dalam pencegahan DBD, proporsi pemain dewasa yang keberatan dengan pelibatan anak untuk menguras ember atau bak di rumah lebih kecil dibandingkan dengan menguras ember atau bak di sekolah. Hal ini menunjukkan bahwa orang tua lebih menyetujui jika anakanak diminta mengerjakan hal-hal tersebut di rumah dibandingkan dengan di sekolah. Namun demikian, setelah memainkan game Jumantik, proporsi orang dewasa yang menyetujui pelibatan anak dalam menguras ember di sekolah meningkat. Hal ini merupakan informasi penting yang dapat digunakan untuk menentukan sejauh mana anak-anak dapat dilibatkan dalam pencegahan DBD di rumah dan di sekolah. Distribusi sikap peserta sebelum dan sesudah mengikuti permainan dapat dilihat pada tabel 2 dan tabel 3.

Tabel2. Sikap pemain anak terkait Demam Berdarah Dengue sebelum dan setelah bermain game Jumantik

\begin{tabular}{|c|c|c|c|c|c|c|c|c|c|}
\hline \multirow[t]{2}{*}{ No } & \multirow[t]{2}{*}{ Pernyataan } & \multicolumn{4}{|c|}{$\begin{array}{c}\text { Pretes } \\
\mathrm{N}=9\end{array}$} & \multicolumn{4}{|c|}{$\begin{array}{c}\text { Postes } \\
\mathrm{N}=9\end{array}$} \\
\hline & & $\mathrm{S}$ & $\mathrm{R}$ & TS & TM & $\mathrm{S}$ & $\mathrm{R}$ & TS & TM \\
\hline 1 & $\begin{array}{l}\text { Demam berdarah merupakan penyakit } \\
\text { yang berbahaya }\end{array}$ & 8 & 1 & 0 & 0 & 8 & 1 & 0 & 0 \\
\hline 2 & Setiap orang bisa terkena demam berdarah & 9 & 0 & 0 & 0 & 9 & 0 & 0 & 0 \\
\hline 3 & Demam berdarah bisa dicegah & 8 & 1 & 0 & 0 & 9 & 0 & 0 & 0 \\
\hline 4 & $\begin{array}{l}\text { Pencegahan demam berdarah adalah } \\
\text { tanggung jawab bersama }\end{array}$ & 9 & 0 & 0 & 0 & 8 & 1 & 0 & 0 \\
\hline 5 & Saya bisa ikut mencegah demam berdarah & 5 & 4 & 0 & 0 & 5 & 3 & 1 & 0 \\
\hline 6 & $\begin{array}{l}\text { Mencegah demam berdarah adalah } \\
\text { tanggung jawab orang dewasa saja }\end{array}$ & 0 & 1 & 8 & 0 & 1 & 1 & 7 & 0 \\
\hline 7 & $\begin{array}{l}\text { Mencegah demam berdarah adalah } \\
\text { tanggung jawab pemerintah saja }\end{array}$ & 1 & 0 & 8 & 0 & 1 & 0 & 8 & 0 \\
\hline 8 & $\begin{array}{l}\text { Satu-satunya cara mencegah demam } \\
\text { berdarah adalah dengan melakukan } \\
\text { fogging (pengasapan) }\end{array}$ & 3 & 4 & 2 & 0 & 5 & 2 & 2 & 0 \\
\hline 9 & $\begin{array}{l}\text { Saya mengetahui tempat-tempat yang } \\
\text { disukai nyamuk penular demam berdarah }\end{array}$ & 6 & 3 & 0 & 0 & 6 & 3 & 0 & 0 \\
\hline 10 & Saya bisa mengenali jentik-jentik nyamuk & 5 & 4 & 0 & 0 & 7 & 2 & 0 & 0 \\
\hline
\end{tabular}




\begin{tabular}{|c|l|c|c|c|c|c|c|c|c|}
\hline 11 & $\begin{array}{l}\text { Saya bisa membasmi jentik nyamuk di } \\
\text { rumah }\end{array}$ & 5 & 1 & 1 & 6 & 2 & 1 & 0 \\
\hline 12 & $\begin{array}{l}\text { Saya bisa membasmi jentik nyamuk di } \\
\text { sekolah }\end{array}$ & 5 & 2 & 1 & 1 & 6 & 2 & 1 & 0 \\
\hline 13 & $\begin{array}{l}\text { Dengan menguras bak mandi seminggu } \\
\text { sekali saya dapat mencegah demam } \\
\text { berdarah }\end{array}$ & 5 & 2 & 2 & 0 & 6 & 3 & 0 & 0 \\
\hline 14 & $\begin{array}{l}\text { Dengan menutup ember air saya dapat } \\
\text { mencegah demam berdarah }\end{array}$ & 7 & 0 & 0 & 2 & 7 & 2 & 0 & 0 \\
\hline 15 & $\begin{array}{l}\text { Saya keberatan jika diminta menguras bak } \\
\text { mandi di rumah }\end{array}$ & 2 & 2 & 3 & 2 & 1 & 3 & 5 & 0 \\
\hline 16 & $\begin{array}{l}\text { Saya keberatan jika diminta menguras } \\
\text { ember di rumah }\end{array}$ & 2 & 2 & 3 & 2 & 1 & 3 & 5 & 0 \\
\hline 17 & $\begin{array}{l}\text { Saya keberatan jika diminta memeriksa ada } \\
\text { tidaknya jentik nyamuk di rumah }\end{array}$ & 1 & 4 & 2 & 2 & 1 & 1 & 7 & 0 \\
\hline 18 & $\begin{array}{l}\text { Saya keberatan jika diminta menguras bak } \\
\text { mandi di sekolah }\end{array}$ & 2 & 3 & 3 & 1 & 2 & 2 & 5 & 0 \\
\hline 19 & $\begin{array}{l}\text { Saya keberatan jika diminta menguras } \\
\text { ember di sekolah }\end{array}$ & 2 & 3 & 3 & 1 & 2 & 2 & 5 & 0 \\
\hline 20 & $\begin{array}{l}\text { Saya keberatan jika diminta memeriksa ada } \\
\text { tidaknya jentik nyamuk di sekolah }\end{array}$ & 3 & 2 & 3 & 1 & 2 & 1 & 6 & 0 \\
\hline 21 & $\begin{array}{l}\text { Jika di sekolah ada yang terkena demam } \\
\text { berdarah, maka sekolah harus di fogging }\end{array}$ & 6 & 2 & 0 & 1 & 7 & 2 & 0 & 0 \\
\hline $\begin{array}{l}\text { Jika di lingkungan rumah saya ada yang } \\
\text { terkena demam berdarah, maka lingkungan } \\
\text { rumah saya harus di fogging }\end{array}$ & 7 & 1 & 0 & 1 & 8 & 1 & 0 & 0 \\
\hline
\end{tabular}

Keterangan : S = Setuju; R = Ragu-ragu; TS = Tidak Setuju; TM = Tidak Menjawab

Tabel 3. Sikap pemain dewasa terkait Demam Berdarah Dengue sebelum dan setelah bermain game Jumantik

\begin{tabular}{|c|c|c|c|c|c|c|c|c|c|c|c|}
\hline \multirow[t]{2}{*}{ No } & \multirow[t]{2}{*}{ Pernyataan } & \multicolumn{5}{|c|}{$\begin{array}{l}\text { Pretes } \\
\mathrm{N}=11\end{array}$} & \multicolumn{5}{|c|}{$\begin{array}{l}\text { Postes } \\
\mathrm{N}=10\end{array}$} \\
\hline & & SS & $\mathrm{S}$ & RR & TS & STS & SS & $\mathrm{S}$ & RR & TS & STS \\
\hline 1 & $\begin{array}{l}\text { Demam berdarah merupakan } \\
\text { penyakit yang berbahaya }\end{array}$ & 8 & 3 & 0 & 0 & 0 & 7 & 3 & 0 & 0 & 0 \\
\hline 2 & $\begin{array}{l}\text { Setiap orang bisa terkena } \\
\text { demam berdarah }\end{array}$ & 8 & 3 & 0 & 0 & 0 & 9 & 1 & 0 & 0 & 0 \\
\hline 3 & $\begin{array}{l}\text { Demam berdarah bisa } \\
\text { dicegah }\end{array}$ & 8 & 3 & 0 & 0 & 0 & 10 & 0 & 0 & 0 & 0 \\
\hline 4 & $\begin{array}{l}\text { Pencegahan } \\
\text { berdarah adalah tanggung } \\
\text { jawab bersama }\end{array}$ & 8 & 3 & 0 & 0 & 0 & 10 & 0 & 0 & 0 & 0 \\
\hline 5 & $\begin{array}{l}\text { Saya bisa ikut mencegah } \\
\text { demam berdarah }\end{array}$ & 7 & 4 & 0 & 0 & 0 & 6 & 4 & 0 & 0 & 0 \\
\hline 6 & $\begin{array}{l}\text { Anak-anak juga dapat ikut } \\
\text { berperan mencegah demam } \\
\text { berdarah }\end{array}$ & 3 & 7 & 1 & 0 & 0 & 8 & 2 & 0 & 0 & 0 \\
\hline 7 & $\begin{array}{l}\text { Mencegah demam berdarah } \\
\text { adalah tanggung jawab } \\
\text { pemerintah saja }\end{array}$ & 1 & 0 & 0 & 5 & 5 & 2 & 0 & 0 & 4 & 4 \\
\hline 8 & $\begin{array}{l}\text { Satu-satunya cara mencegah } \\
\text { demam berdarah adalah }\end{array}$ & 2 & 1 & 0 & 8 & 0 & 1 & 1 & 0 & 7 & 1 \\
\hline
\end{tabular}




\begin{tabular}{|c|c|c|c|c|c|c|c|c|c|c|c|}
\hline & $\begin{array}{l}\text { dengan melakukan fogging } \\
\text { (pengasapan) }\end{array}$ & & & & & & & & & & \\
\hline 9 & $\begin{array}{l}\text { Saya mengetahui tempat- } \\
\text { tempat yang disukai nyamuk } \\
\text { penular demam berdarah }\end{array}$ & 3 & 6 & 1 & 1 & 0 & 3 & 7 & 0 & 0 & 0 \\
\hline 10 & $\begin{array}{l}\text { Saya bisa mengenali jentik- } \\
\text { jentik nyamuk }\end{array}$ & 4 & 6 & 1 & 0 & 0 & 3 & 7 & 0 & 0 & 0 \\
\hline 11 & $\begin{array}{l}\text { Saya bisa membasmi jentik } \\
\text { nyamuk di rumah }\end{array}$ & 3 & 8 & 0 & 0 & 0 & 3 & 7 & 0 & 0 & 0 \\
\hline 12 & $\begin{array}{l}\text { Saya bisa membasmi jentik } \\
\text { nyamuk di lingkungan tempat } \\
\text { kerja }\end{array}$ & 2 & 8 & 1 & 0 & 0 & 3 & 7 & 0 & 0 & 0 \\
\hline 13 & $\begin{array}{l}\text { Dengan menguras bak mandi } \\
\text { seminggu sekali saya dapat } \\
\text { mencegah demam berdarah }\end{array}$ & 4 & 7 & 0 & 0 & 0 & 5 & 4 & 1 & 0 & 0 \\
\hline 14 & $\begin{array}{l}\text { Dengan menutup ember air } \\
\text { saya dapat mencegah demam } \\
\text { berdarah }\end{array}$ & 4 & 6 & 0 & 1 & 0 & 5 & 4 & 0 & 1 & 0 \\
\hline 15 & $\begin{array}{lr}\text { Anak-anak dapat dilatih } \\
\text { mengenali } & \text { jentik-jentik } \\
\text { nyamuk } & \\
\end{array}$ & 4 & 6 & 1 & 0 & 0 & 4 & 6 & 0 & 0 & 0 \\
\hline 16 & $\begin{array}{l}\text { Anak-anak dapat dilatih } \\
\text { membasmi jentik nyamuk }\end{array}$ & 4 & 7 & 0 & 0 & 0 & 3 & 7 & 0 & 0 & 0 \\
\hline 17 & $\begin{array}{l}\text { Saya keberatan jika anak - } \\
\text { anak diminta menguras bak } \\
\text { mandi di rumah }\end{array}$ & 1 & 1 & 2 & 6 & 1 & 0 & 1 & 0 & 8 & 1 \\
\hline 18 & $\begin{array}{l}\text { Saya keberatan jika anak - } \\
\text { anak diminta menguras } \\
\text { ember di rumah }\end{array}$ & 0 & 1 & 3 & 5 & 2 & 0 & 1 & 0 & 8 & 1 \\
\hline 19 & $\begin{array}{l}\text { Saya keberatan jika anak - } \\
\text { anak diminta memeriksa ada } \\
\text { tidaknya jentik nyamuk di } \\
\text { rumah }\end{array}$ & 0 & 2 & 2 & 5 & 2 & 0 & 1 & 0 & 8 & 1 \\
\hline 20 & $\begin{array}{l}\text { Saya keberatan jika anak - } \\
\text { anak diminta menguras bak } \\
\text { mandi di sekolah }\end{array}$ & 0 & 3 & 3 & 3 & 2 & 0 & 4 & 1 & 4 & 1 \\
\hline 21 & $\begin{array}{l}\text { Saya keberatan jika anak - } \\
\text { anak diminta menguras } \\
\text { ember di sekolah }\end{array}$ & 0 & 3 & 2 & 4 & 2 & 0 & 2 & 2 & 5 & 1 \\
\hline 22 & $\begin{array}{l}\text { Saya keberatan jika anak - } \\
\text { anak diminta memeriksa ada } \\
\text { tidaknya jentik nyamuk di } \\
\text { sekolah }\end{array}$ & 0 & 3 & 2 & 4 & 2 & 0 & 0 & 2 & 7 & 1 \\
\hline 23 & $\begin{array}{l}\text { Jika ada yang terkena demam } \\
\text { berdarah di sekolah, maka } \\
\text { sekolah harus di fogging }\end{array}$ & 5 & 3 & 2 & 1 & 0 & 1 & 7 & 2 & 0 & 0 \\
\hline 24 & $\begin{array}{l}\text { Jika ada yang terkena demam } \\
\text { berdarah di lingkungan } \\
\text { rumah, maka lingkungan saya } \\
\text { harus di fogging }\end{array}$ & 6 & 3 & 2 & 0 & 0 & 1 & 7 & 2 & 0 & 0 \\
\hline 25 & $\begin{array}{l}\text { Jika ada rekan kerja yang } \\
\text { terkena demam berdarah, } \\
\text { maka tempat kerja saya harus } \\
\text { di fogging }\end{array}$ & 5 & 2 & 2 & 1 & 0 & 1 & 6 & 2 & 1 & 0 \\
\hline
\end{tabular}


Keterangan : SS = Sangat Setuju; S = Setuju; RR = Ragu-ragu; TS = Tidak Setuju; STS = Sangat Tidak Setuju

Umpan balik

Rerata skor yang diberikan pemain anak terhadap game ini adalah 85.7 sementara rerata skor yang diberikan pemain dewasa adalah 82.8. Hal ini menunjukkan bahwa game Jumantik disukai oleh anak-anak maupun dewasa.

\section{KESIMPULAN}

Permainan Jumantik mampu meningkatkan pengetahuan anakanak maupun dewasa tentang Demam Berdarah Dengue, terutama mengenai cara menanggulangi breeding site nyamuk yang umum dijumpai di rumah dan di sekolah. Setelah bermain game ini, anak-anak menjadi lebih tertarik untuk terlibat mengenali keberadaan jentik-jentik nyamuk di rumah dan di sekolah.

Permainan ini dinilai menarik dan bermanfaat dimainkan oleh peserta baik anak-anak maupun dewasa sehingga memiliki potensi untuk digunakan dalam mengedukasi masyarakat tentang pencegahan Demam Berdarah Dengue terutama pemantauan jentik nyamuk. Ke depannya, permainan ini dapat digunakan oleh sekolah, guru, dan pemegang program di Puskesmas untuk meningkatkan partisipasi masyarakat dalam pencegahan Demam Berdarah Dengue.

\section{UCAPAN TERIMA KASIH}

Tim pelaksana kegiatan pengabdian kepada masyarakat ini mengucapkan terima kasih kepada: Fakultas Kedokteran Universitas Mataram dan Lembaga Penelitian dan Pengabdian Kepada Masyarakat yang telah mendanai kegiatan ini melalui sumber dana DIPA BLU (PNBP) tahun 2018; DAKON sebagai pengembang permainan JUMANTIK; dan Rumah Sakit Universitas Mataram sebagai salah satu lokasi uji coba permainan JUMANTIK.

\section{DAFTAR PUSTAKA}

Aguiar, M., Stollenwerk, N., Halstead, S.B. 2016. The Impact of the Newly Licensed Dengue Vaccine in Endemic Countries. PLoS Neglected Tropical Diseases, 10(12): e0005179. https://doi.org/10.1371/journ al.pntd.0005179 
Dinas Kesehatan Kota Mataram, 2016. Perkembangan Sebaran Kasus DBD di Kota Mataram [presentasi yang belum dipublikasikan]. Dinas Kesehatan Kota Mataram.

Giannakos M.N, (2013) "Enjoy and learn with educational games: Examining factors affecting learning performance," Computers $\&$ Education, vol. 68, pp. 429 439, 2013.

Josafat, A, dkk .2016. Studi Fase I Intervensi Demam Berdarah Berbasis Sekolah: Pengumpulan Data Dasar Upaya Sekolah Dasar dalam Melakukan Intervensi Pencegahan Demam Berdarah di Lingkungan Sekolah Di Kota Mataram . Laporan Penelitian PNBP, Universitas Mataram.

Karyanti, M.R. et al., 2014. The Changing Incidence of Dengue Haemorrhagic Fever in Indonesia: A 45-Year Registrybased Analysis. BioMed Central Infectious Diseases.

Mohammed, A. and Chadee, D.D. 2011. Effects of different temperature regimens on the development of aedes aegypti (I.) (diptera: Culicidae) mosquitoes. Acta Tropica, 119 (1), pp. 38-43

Mostowfi, M., Mamaghani, N.K., Khorramar, M. (2016) 'Designing Playful Learning by Using Educational Board Game for Children in the Age Range of 7-12: (A Case Study: Recycling and Waste Seperation
Education Board Game), International Journal of Environmental and Science Education, 11(12), pp. 54535476.

Ober, C. P. (2016) Assessment of Student Engagement When Using a Novel Board Game for Teaching Thoracic Radiography to Fourth-Year Veterinary Students. Medical Science Educator, 26(1), pp 39-42.

Padmanabha, H., Soto, E., Mosquera, M., Lord, C.and Lounibos, L. 2010. Ecological links between water storage behaviors and aedes aegypti production: implications for dengue vector control in variable climates. Ecohealth 7 (1), pp. 78-90

Viggiano, E., et al. (2018) Healthy lifestyle promotion in primary schools through the board game Kaledo: a pilot cluster randomized trial. European Journal of Pediatrics, 1-5

Winch, P.J. Leontsini, E., Rigau-P'erez, J.G., Ruiz-P'erez, M., Clark, G.G., and Gubler, D.J. 2002. Community-based dengue prevention programs in puerto rico: impact on knowledge, behavior, and residential mosquito infestation. The American Journal of Tropical Medicine and Hygiene, 67 (4) pp. $363-370$

World Health Organization, 2009. Dengue: Guidelines for Diagnosis, Treatment, Prevention, and Control.

World Health Organization, 2011. Comprehensive Guidelines for 
Prevention and Control of Dengue and Dengue Haemorrhagic Fever.
World Health Organization, 2012. Global Strategy for Dengue Prevention and Control 20122020. 